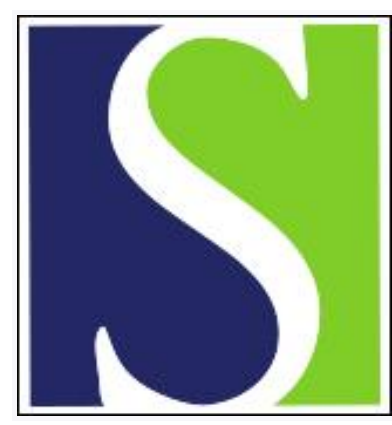

Scand J Work Environ Health 1979;5(2):71-90

https://doi.org/10.5271/sjweh.2664

Issue date: Jun 1979

\title{
Toluene. A toxicologic review.
}

by Cohr Karl-Heinz, Stokholm J

The following article refers to this text: 1980;6(2):158-160

Key terms: hygienic threshold value; metabolism; occupational exposure; occupational exposure; review; threshold limit value; toluene; toxicologic review

This article in PubMed: www.ncbi.nlm.nih.gov/pubmed/382346

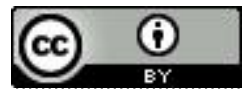


Scand. j. work environ. \& health 5 (1979) $71-90$

\section{Toluene}

\section{A toxicologic review ${ }^{1}$}

by KARL-HEINZ COHR, M.Sc., and JENS STOKHOLM, M.D. ${ }^{2}$

COHR, K.-H. and STOKHOLM, J. Toluene: A toxicologic review. Scand. j. work environ. \& health 5 (1979) $71-90$. This review is a critical survey and evaluation of the recent literature relevant as medical background for a discussion of hygienic threshold values for toluene.

Key words: hygienic threshold value, metabolism, occupational exposure, threshold limit value, toluene.

This review is a slightly revised version of a criteria document prepared for the Nordic Expert Group on Hygienic Threshold Values under the Nordic Council of Ministers (8). A critical evaluation of the recent literature is made on the basis of Criteria for a Recommended Standard: Occupational Exposure to Toluene (98). Of the available publications only those which are considered to form a reliable and relevant medical basis for the establishment of a hygienic threshold value have been included.

1 This review is a slightly revised version of a criteria document compiled for the Nordic Expert Group on Hygienic Threshold Values under the Nordic Council of Ministers, published in the series Arbete och Hälsa.

2 National Institute of Working Environment, Labor Inspection Service, Copenhagen, Denmark.

Requests for reprints: Karl-Heinz Cohr, Arbejdsmiljøinstituttet, Baunegårdsvej 73, DK2900 Hellerup, Denmark.

\section{FIELDS OF APPLICATION}

Toluene is a colorless liquid. It is used as a solvent, a thinner, and as a basic material in a large number of chemical industries using toluene for the manufacture of toluene disocyanate, phenol, benzene, nitrotoluenes, vinyl toluenes, paints, lacquers, adhesives, etc.

Furthermore hazardous exposure to toluene-containing colors, lacquers, glues, thinners, cleaning liquids, etc., can occur during painting and lacquering in the lumber and furniture industries; occasionally during the painting of buildings, car painting and other metal painting; during such work as linoleum laying; and also in the rubber, plastics, leather and tanning industries. In these industries toluene may also be used for dyeing. Finally, toluene is widely used in the printing industry.

There has been a steady increase in the application of toluene for synthetic use, etc., allowance being made for market fluctuations. In the chemical industry toluene is generally used at stationary 
work sites where exposure is normally limited to the processes of cleaning and repairing machines.

When toluene is used as a solvent and a thinner in paints, lacquers, adhesives and cleaners, hazards from exposure are likely to occur in small areas where the worker is mobile and where the rate of evaporation is high and exhaust facilities are few. Therefore the greatest hazards from exposure are found in this type of exposure.

Endeavors are being made to develop paints, lacquers and adhesives based on water as a vehicle and thinner for the binding agents, pigments and adhesives. A few products have already been developed, especially of the adhesive type. Successful further development of these products will reduce toluene exposure considerably.

Some of the physicochemical properties of toluene follow.

\begin{tabular}{|c|c|}
\hline Systematic name & methylbenzene \\
\hline Synonyms & toluene, toluol \\
\hline CAS number & $108-88-3$ \\
\hline Molecular formula & $\mathrm{C}_{6} ; \mathrm{H}_{5} \mathrm{CH}_{3}$ \\
\hline Structural formula & \\
\hline Molecular weight & 92.13 \\
\hline $\begin{array}{l}\text { State at } \\
25^{\circ} \mathrm{C}, 101.3 \mathrm{kPa}\end{array}$ & colorless liquid \\
\hline $\begin{array}{l}\text { Boiling point at } \\
101.3 \mathrm{kPa}\end{array}$ & $110.6^{\circ} \mathrm{C}$ \\
\hline $\begin{array}{l}\text { Vapor pressure } \\
\text { at } 25^{\circ} \mathrm{C}\end{array}$ & $\begin{array}{l}3.73 \mathrm{kPa}(\sim 137,500 \mathrm{mg} / \\
\left.\mathrm{m}^{3}\right)\end{array}$ \\
\hline Solubility & $\begin{array}{l}\text { about } 6.5 \mathrm{mmol} / 1 \text { of wa- } \\
\text { ter at } 20{ }^{\circ} \mathrm{C} \text {; soluble in } \\
\text { acetone, miscible with } \\
\text { ethanol, diethyl ether } \\
\text { and benzene }\end{array}$ \\
\hline Conversion factor & $\begin{array}{l}1 \mathrm{mg} / \mathrm{m}^{3}=0.267 \mathrm{ppm} \\
1 \mathrm{ppm}=3.75 \mathrm{mg} / \mathrm{m}^{3}\end{array}$ \\
\hline
\end{tabular}

\section{METABOLISM}

\section{Absorption through the lungs}

The retention of toluene by the lungs depends on the ventilation of the lungs, the concentration gradient over the alveolar wall, the distribution coefficient blood/air for toluene, and, to a smaller extent, on the blood circulation through the alveoli (1).

At a given concentration of toluene in inhaled air, the concentration in the alveolar air and arterial blood quickly increases during the first $10-15 \mathrm{~min}$. Already after $10 \mathrm{~s}$ of exposure it is possible to detect the presence of toluene in arterial blood (2). After that the concentration increases more slowly and reaches a fairly constant level after about 25 min $(1,2)$. During this period the retention is $75-80 \%(2,109)$.

The rate of retention decreases as the organism approaches a state of equilibrium with respect to the absorption, deposition and excretion of toluene and its metabolites. After $2-3 \mathrm{~h}$ of exposure the rate of retention falls to an almost constant level - approximately 40-50\% (99, $109,123,139)$. The average rate of retention over a period of $5 \mathrm{~h}$ is approximately $50 \%$ (123). Dogs absorb about 3-4 \% through the upper respiratory tract (32).

Absorption expressed as a function of time may be described as a sum of three exponential terms (117), which are reduced to the following:

$$
\mathrm{Y}=\mathrm{A}\left(1-\mathrm{e}^{-a \mathrm{t}}\right),
$$

when retention reaches a constant level (142). $\mathrm{Y}$ is the body concentration to the time $t, A$ is the body concentration at equilibrium, and $\alpha$ is the time constant.

\section{Gastrointestinal tract}

Case reports on accidents and suicide attempts, as well as attempts at curing leukemia with toluene (16), show that toluene may be absorbed through the gastrointestinal tract.

Animal experiments have shown that toluene is absorbed more slowly via the gastrointestinal tract than via the lungs. The blood concentration reaches its maximum $2 \mathrm{~h}$ after oral administration (110). Absorption is almost $100 \%$ in that $76 \%$ recurs in the form of hippuric acid in the urine (73) and about $18 \%$ is excreted in the form of toluene vapors via the lungs (121). 
Table 1. Volumes and perfusion of the four tissue groups, their distribution coefficients, biological half-times and distribution volumes for toluene.

\begin{tabular}{|c|c|c|c|c|c|}
\hline \multirow[b]{2}{*}{ Parameter } & \multirow[b]{2}{*}{$\begin{array}{l}\text { Symbol } \\
\text { (unit) }\end{array}$} & \multicolumn{3}{|c|}{ Tissue group } & \multirow[b]{2}{*}{ Vessel poor } \\
\hline & & Vessel rich & Muscle & Fat & \\
\hline Volume in a $70-\mathrm{kg}$ person & $\mathrm{V}(1)$ & 6.0 & 33.0 & 14.5 & $12.5^{\mathrm{a}}$ \\
\hline $\begin{array}{l}\text { Percentage of the minute } \\
\text { volume of the heart to } \\
\text { tissue group }\end{array}$ & $\%$ & 75.0 & 18.1 & 5.4 & 1.5 \\
\hline $\begin{array}{l}\text { Perfusion in a } 70-\mathrm{kg} \\
\text { person at a heart-minute } \\
\text { volume of } 7 \mathrm{l} / \mathrm{min}\end{array}$ & $\dot{\mathrm{V}}(1 / \mathrm{min})$ & 5.25 & 1.27 & 0.38 & 0.10 \\
\hline $\begin{array}{l}\text { Tissue/blood distribution } \\
\text { coefficient (rabbit) b }\end{array}$ & $\lambda$ & 2.3 & 1.6 & 74.3 & 1.9 \\
\hline $\begin{array}{l}\text { Tissue/blood distribution } \\
\text { coefficient (human) } \mathbf{c}\end{array}$ & $\lambda$ & - & - & $81-83$ & - \\
\hline Biological half-time & $t_{1 / 2}(h)$ & $2 \min$ & 0.5 & 77 & 2.8 \\
\hline Distribution volume & $V_{\text {lisit }}(\mathrm{l})$ & 14 & 53 & 1,189 & 23 \\
\hline
\end{tabular}

a This value includes lung tissue corresponding to $0.5 \mathrm{l}$.

b From Sato et al. (117).

c From Sato et al. (117) and Sherwood (120).

\section{Absorption through the skin}

With exposure to $2,250 \mathrm{mg} / \mathrm{m}^{3}$ (600 $\left.\mathrm{ppm}\right)$ of toluene for $3.5 \mathrm{~h}$ a quantity corresponding to approximately $0.9 \%$ of alveolar retention has been shown to be absorbed through the skin, as measured by the exhaled amount (112). Exposure of skin to $1,600 \mathrm{mg} / \mathrm{m}^{3}$ of toluene for $8 \mathrm{~h}$ did not result in any abnormal excretion of hippuric acid (109).

Liquid toluene is absorbed through the skin at rates of $150-250 \mu \mathrm{mol} / \mathrm{cm}^{2} \mathrm{~h}(14-$ $23 \mathrm{mg} / \mathrm{cm}^{2} \mathrm{~h}$ ). In the case of aqueous toluene solutions the rate of absorption is proportional to the concentration (31). Transportation from the skin is very slow. After $10 \mathrm{~min}$ of immersion of both hands the values of the toluene concentration in exhaled air is about 25 times lower than those observed after $2 \mathrm{~h}$ of exposure to $375 \mathrm{mg} / \mathrm{m}^{3}(100 \mathrm{ppm})(52,116)$. After a subcutaneous injection of toluene into animals the blood concentration reaches its maximum after $4 \mathrm{~h}$ (42).

\section{Distribution}

The solubility of toluene in blood is indicated by the distribution coefficient blood/air, observed to be $11.2-15.6$ at $37^{\circ} \mathrm{C}(80,114,115,120,143)$. This distribution coefficient is independent of the hematocrit value (114) and of the hemoglobin content of the blood (80).

Toluene is not very water-soluble (approximately $6.5 \mathrm{mmol} / 1$ at $20^{\circ} \mathrm{C}$ ), and hence it must bind to the lipids and the lipoproteins of the plasma - primarily those of the chylomicrons $(42,117,143)$. The solubility of toluene in lipids decreases with the increase of electric charges and possible polarity. The distribution coefficients cholesterol/blood and triolein/blood are thus 3.5 and 115, respectively (117).

The quantity of toluene absorbed by a tissue depends on the distribution coefficient tissue/blood, on the duration of exposure, and on the rate of metabolism. The rate of its absorption depends on the perfusion of the tissue and on the concentration gradient.

The human organism is divided into the following four tissue groups by anesthesiologists (106): VRG: vessel rich group (brain, heart, liver, intestines, kidneys, and endocrine glands); MG: muscle group (muscles and skin); FG: fat group (fatty tissue and yellow bone marrow); VPG: vessel poor group (bones, connective tissues, lung tissue). This division is appropriate for an examination of the distribution of toluene. Table 1 shows the volumes 
and perfusion of these tissue groups in relation to determined distribution coefficients (rabbit tissue), biological half-time and distribution volumes, the distribution volume being $\mathrm{V}_{\mathrm{dist}}=\mathrm{V} \cdot \lambda$ and the biological half-time being $t_{1 / 2}=V_{d i s t} \cdot \ln 2 / \dot{V}$. In the mentioned biological half-time, biotransformation has been disregarded.

The distribution coefficient tissue/blood is $1-3$ for all tissue groups except $F G$, for which it is about 80. The distribution volume tells directly how much toluene (expressed in millimoles) can accumulate in the tissue at a blood concentration of 1 $\mathrm{mmol} / \mathrm{l}$. The largest quantity of toluene accumulates in FG, and this accumulation is in accordance with the fact that retention is positively dependent on a person's amount of fat (21).

Furthermore animal experiments have shown a relatively high distribution to the stomach wall in the case of inhalation [distribution coefficient stomach/blood = 4-5 (110)].

There are no data available on the effects of toluene passing through the placenta.

\section{Biotransformation}

Toluene is transformed mainly in the microsomes of the liver parenchymal cells by oxidation in one out of several possible positions $(45,94)$. Benzoic acid is the most important product of such transformation $(18,43,146)$. It is formed by oxidation of the methyl group of toluene via benzyl alcohol and benzaldehyde (73). Benzyl alcohol has been detected in the urine of rats (10), but benzaldehyde has not been found in either urine or expired air $(10,121)$. It is possible that benzyl alcohol is formed by a free benzyl radical (149).

In rat liver the rate at which toluene is oxidized to benzoic acid has been found to be $0.6 \mathrm{mmol} \cdot \mathrm{h}^{-1} / \mathrm{kg}$ of liver (56). Some 75 to $80 \%$ of the quantity of toluene absorbed is converted to benzoic acid (73).

In the human organism toluene is almost exclusively converted to benzoic acid (124). However, there are indications that small quantities may be converted to phenolic compounds both in human beings and in animals $(10,38,44,130)$. By the oxidation of toluene in the aromatic nucleus $0.1 \%$ has been converted to o-cresol and $1 \%$ to p-cresol, but none to m-cresol $(10,76,141)$. This oxidation is catalyzed by the enzyme arylmonoozygenase, and it takes place by epoxide formation $(66,67)$. Furthermore it has been stated that small quantities of toluene may be transformed to pyrocatechol and $\beta$-ketoadipic acid (13).

The metabolites formed from toluene are made more readily water-soluble by conjugation with suitable compounds (146). Benzoic acid is conjugated with glycine to form hippuric acid $(73,87,124$, 146) and with glucuronic acid to form benzoylglucuronide $(13,76,114,139)$. Benzyl alcohol and phenolic derivatives are conjugated with glucuronic acid and sulfate $(10,44,76,130)$.

\section{Elimination through the lungs}

The exhaled quantity of toluene depends on the difference between the concentrations in blood and alveolar air, the distribution coefficient blood/air, and ventilation. The minute volume of the heart is comparatively insignificant in the case of toluene, which has a relatively high blood/air distribution coefficient (47).

The concentration of toluene in the exhaled air falls rapidly during the first 10 min after exposure $(1,2)$. Two hours after exposure the concentration in the exhaled air is very low $(1,2,103) ; 15-20 \%$ of the absorbed quantity of toluene is exhaled $(43,99,100,121,123,139)$.

\section{Elimination through the kidneys}

The elimination of toluene and its derivatives also takes place through the kidneys. Eighty percent of the benzoic acid is excreted as hippuric acid $(124,146)$ and $20 \%$ as benzoyl glucuronide $(13,76,103$, $124,139)$. Phenolic derivatives $(10,44,130)$ are excreted as glucuronides and sulfates $(44,76)$. Besides, small quantities of benzyl alcohol are excreted (10). Small quantities of toluene - corresponding to the solubility of toluene in water - are excreted unchanged $(123,139)$. 


\section{Elimination through the gastrointestinal} tract

Less than $2 \%$ of absorbed toluene is excreted unchanged and as metabolites via the bile to the intestine (3). A large quantity of these excretions is resorbed so that only small amounts of toluene are excreted in feces. Toluene may be excreted unchanged or converted from the stomach wall to the contents of the stomach (110).

\section{Other paths of excretion}

The toluene absorbed by the skin, owing to skin contact with liquid toluene, quickly evaporates when skin contact ends $(52,146)$.

\section{Biological half-time}

Table 1 shows the biological half-times for the four tissue groups. Toluene is distributed to the various tissues in amounts corresponding to the perfusion of the tissues, which is expressed as the percentage of the minute volume of the heart.
Therefore, for the VRG tissues with very short bioligical half-times, peak concentrations of even short duration may quickly result in high concentrations. In the cerebral and nervous tissues they may theoretically result in very high local concentrations in lipid-rich structures.

The concentration of toluene in alveolar air follows the concentration in venous blood after exposure. Concentration expressed as a function of time may, in both cases, be described as a sum of exponential terms as follows:

$$
\mathrm{Y}=\mathrm{A}_{1} \mathrm{e}^{-r 1 \mathrm{t}}+\mathrm{A}_{2} \mathrm{e}^{-a 2 \mathrm{t}}+\mathrm{A}_{3} \mathrm{e}^{-u 3 \mathrm{t}} .
$$

The figures indicate various compartments, which are often interpreted physiologically as tissue groups $(1 \sim$ VRG; $2 \sim \mathrm{MG}+\mathrm{VPG} ; 3 \sim \mathrm{FG}$ ). The $A$ 's correspond to the contributions to the blood/ alveolar air concentration ( $\mathrm{Y}$ ) from the respective tissue groups at the end of exposure. The $-\alpha$ 's are the time constants for the reduction of the contributions of the respective tissue groups to the blood/ alveolar air concentration; $a$ implicitly involves biotransformation in the tissue groups. Table 2 shows determined values for $A$ and $\alpha$.

Table 2. Experimentally determined values of the constants $\mathrm{A}$ and $a$ in equation $\mathrm{b}$ for venous blood and alveolar air in humans.

\begin{tabular}{|c|c|c|c|c|c|c|}
\hline \multirow{2}{*}{ Constant } & \multirow{2}{*}{ Sex } & \multicolumn{3}{|c|}{ Compartment } & \multirow{2}{*}{ Unit } & \multirow{2}{*}{ Reference } \\
\hline & & 1 & 2 & 3 & & \\
\hline \multicolumn{7}{|l|}{ A } \\
\hline \multirow[t]{2}{*}{ Venous blood } & Male & 3.85 & 3.82 & 1.40 & $/ 1 \mathrm{~mol} / \mathrm{I}$ & $\begin{array}{l}\text { Sato and Fujiwara (113) } \\
\text { and Sato et al. (117) }\end{array}$ \\
\hline & & $(35.5)$ & $(35.2)$ & $(12.9)$ & $(\mu \mathrm{g} / 100 \mathrm{ml})$ & $\begin{array}{l}\text { Sato and Fujiwara (113) } \\
\text { and Sato et al. (117) }\end{array}$ \\
\hline \multirow[t]{2}{*}{ Alveolar air } & Male & 0.34 & 0.21 & 0.056 & $\mu / \mathrm{mol} / 1$ & $\begin{array}{l}\text { Sato and Fujiwara (113) } \\
\text { and Sato et al. (117) }\end{array}$ \\
\hline & & $(3.17)$ & (1.95) & $(0.513)$ & $(1 / \mathrm{g} / 100 \mathrm{ml})$ & $\begin{array}{l}\text { Sato and Fujiwara (113) } \\
\text { and Sato et al. (117) }\end{array}$ \\
\hline \multicolumn{7}{|l|}{$\alpha$} \\
\hline Venous blood & Male & 0.355 & 0.0197 & 0.00339 & $\min ^{-1}$ & $\begin{array}{l}\text { Sato and Fujiwara (113) } \\
\text { and Sato et al. (117) }\end{array}$ \\
\hline Alveolar air & Male & 0.437 & 0.0262 & 0.00313 & $\min ^{-1}$ & $\begin{array}{l}\text { Sato and Fujiwara (113) } \\
\text { and Sato et al. (117) }\end{array}$ \\
\hline Alveolar air & Male & 5.10 & 0.335 & 一 & $h^{-1}$ & $\begin{array}{l}\text { Nomiyama and Nomi- } \\
\text { yama }(100)\end{array}$. \\
\hline Alveolar air & Female & 3.22 & 0.335 & - & $\mathrm{h}^{-1}$ & $\begin{array}{l}\text { Sato and Fujiwara (113) } \\
\text { and Sato et al. (117) }\end{array}$ \\
\hline
\end{tabular}


Biological half-time may be determined by the relation:

$$
t_{1 / 2}=\ln 2 / \alpha
$$

The biological half-time for hippuric acid in urine has been found to be $74 \mathrm{~min}$ for women and $117 \mathrm{~min}$ for men (101).

\section{Factors affecting metabolism}

In rats the mean lethal dose $\left(\mathrm{LD}_{\overline{70} 0}\right)$ increases for toluene with the years (71). This phenomenon might be related to a change in biotransformation activity, as seen for pharmaceuticals (68).

Women eliminate smaller quantities of toluene through the lungs than men (100) and presumably have a lower concentration of toluene in the blood during the elimination phase. This situation may be related to the fact that the biological halftime for hippuric acid in urine is shorter for women (101). There is no difference between women and men in respect to total hippuric acid excretion over $24 \mathrm{~h}$.

Adipose persons have a lower alveolar air concentration and consequently a higher rate of retention than thin persons (21).

Exposure to $750 \mathrm{mg} / \mathrm{m}^{3}$ (200 $\left.\mathrm{ppm}\right)$ of toluene for $8 \mathrm{~h}$ has been shown to result in the excretion of $17.2 \mathrm{mmol}$ of hippuric acid. This excretion involves a quantity of glycine corresponding to the amount contained in $100 \mathrm{~g}$ of meat (139). Experimental subjects whose diet was supplemented with glycine excreted more hippuric acid (103).

Phenobarbital activates the process of hydroxylation by inducing liver microsomal enzymes $(25,61)$. Rats treated with phenobarbital have shown a lower toluene concentration in the blood than untreated rats (61). The hippuric acid concentration in the urine reached its maximum more quickly and was three to four times higher than in the control animals. Relatively high concentrations of benzoic acid in the blood were detected - normally benzoic acid is not found in blood (61).

Animal experiments have shown that benzene, styrene, and toluene are oxidized by the same enzyme systems in the parenchymal cells of the liver $(58,61,62)$ and that they competitively inhibit the enzymatic transformation of each other (61, 62). Large doses of toluene reduced the concentration of benzene metabolites in tissue and urine and increased the exhalation of benzene. Besides, the decreasing effect of benzene on the incorporation of iron in erythrocytes was inhibited or neutralized depending on the dose ratio of benzene/toluene (6).

Toluene and trichloroethylene, which are not oxidized by the same enzyme systems, noncompetitively inhibit the oxidation of each other (58). Other solvents which are not oxidized by the same enzyme systems do not inhibit the biotransformation of toluene. This phenomenon has been demonstrated with, e.g., n-hexane $(87,127)$ and ethyl acetate $(140)$.

In the case of physical work under constant exposure there is an approximately linear relation between the intensity of work and the toluene concentration in alveolar air and arterial blood. In exposure during light work $(50 \mathrm{~W})$ alveolar air and arterial blood concentrations are double the levels seen with exposure at rest $(1,2)$.

\section{TOXICOLOGIC MECHANISMS}

The toxicologic mechanism of toluene is not known. The lipid-dissolving property of toluene is often used for extracting membrane lipids from cells for the study of intracellular processes in situ. In this connection it has been noted that certain biochemical processes are inhibited, such as protein synthesis (Bacillus subtilis) (148).

\section{ORGAN EFFECTS}

Organ effects have been reported in the nervous system, blood and hematopoietic organs, liver, kidney, heart, mucous membrane, the immune system, and the skin.

\section{Central nervous system}

Like other organic solvents toluene has a predominantly depressing effect on the central nervous system (CNS). 
Experimental exposure to concentrations of up to $3,000 \mathrm{mg} / \mathrm{m}^{3}$ (800 ppm) has produced acute dose-related CNS symptoms such as drowsiness, tiredness, headache, dizziness and nausea. It has also caused impaired coordination, dilatation of the pupils, impaired light accomodation, confusion, and a staggering gait $(23,103)$. The symptoms have also been described in a number of worksite investigations (15, $19,20,82,84,92,147)$. The last-mentioned reports have made no distinction, however, between symptoms lasting only a short time and more lasting symptoms which may indicate irreversible effects on the CNS.

Lasting and possibly irreversible CNS symptoms, disturbances of intellectual, emotional and neurovegetative functions as a result of long-term toluene exposure, have been mentioned primarily in case reports $(49,55,70,74,118)$. All cases involved abuse of toluene over long periods of time (from 3 years and up to 15 years), but other solvents were involved to varying degrees.

With the use of various psychological tests (intelligence, learning, psychomotor and Rorschach tests) the effect of toluene on the CNS has been examined $(54,81,97)$. In $21 \%$ of a group of typographers exposed on the average to $1,125 \mathrm{mg} / \mathrm{m}^{3}(300$ ppm) for 33 years and in $40 \%$ of a group of printers exposed on the average to $1,600 \mathrm{mg} / \mathrm{m}^{3}$ (430 $\left.\mathrm{ppm}\right)$ for 17 years, "organic psychosyndrome" was diagnosed. The tests involved a total of 110 persons (97). Significant differences have also been found, especially for psychomotor tests results, in a comparison of 180 persons exposed to solvents with a reference group (81). Car painters (100 in all), in a stratified sample with a low exposure level to solvents $\left(113 \mathrm{mg} / \mathrm{m}^{3}(30 \mathrm{ppm})\right.$ of toluene), showed small significant differences when compared with a reference group (54). The differences were within the limits of normal variation. Initial comparability was secured on the basis of psychological tests from the military service (54).

For boys (12-16 years of age) with 3 42 months of sniffing behind them, no significant differences were revealed by clinical psychological tests (30).

Experimental exposure of humans to toluene concentrations of $375-2,625$ $\mathrm{mg} / \mathrm{m}^{3}(100-700 \mathrm{ppm})$ for $20 \mathrm{~min}(40)$ and $750 \mathrm{mg} / \mathrm{m}^{3}$ (200 ppm) for $7 \mathrm{~h}$ (105) has shown dose-related extention of simple and choice reaction time, as well as reduced perceptual speed (40).

The neurotoxic effect of toluene has also been examined by neurophysiological and neuroradiological methods. Electroencephalographic (EEG) changes have been described in the case of sniffers $(49,55,74$, 118 ) and for workers poisoned during the performance of their work $(5,135)$. Neuroradiological examinations have shown signs of cerebral atrophia $(55,74$, 118). Exposure to $3,750-19,500 \mathrm{mg} / \mathrm{m}^{3}$ $(1,000-5,200 \mathrm{ppm})$ for $10-30 \mathrm{~min}(5)$ and to $750 \mathrm{mg} / \mathrm{m}^{3}(200 \mathrm{ppm})$ for $6 \mathrm{~h}$ (126) showed no significant changes in the EEG, not even in four epileptics (5).

However, increased EEG activity was observed, even down to the odor threshold, in subjects who were specially trained to develop synchronous and wellmarked alpha rhythm when stimulated by light. The changes in the EEG activity occurred after exposure to $1 \mathrm{mg} / \mathrm{m}^{3}$ for 6 min, but not after exposure to $0.6 \mathrm{mg} / \mathrm{m}^{3}$ for $18 \mathrm{~min}$ (53). These findings are hardly of any pathological importance.

Experimental exposure of rats to 3,750 $15,000 \mathrm{mg} / \mathrm{m}^{3}(1,000-4,000 \mathrm{ppm})$ for $4 \mathrm{~h}$ showed dose-related changes in various EEG components (134).

Increased CNS sensitivity has been detected after eight weeks of exposure to $7,500 \mathrm{mg} / \mathrm{m}^{3} \quad(2,000 \mathrm{ppm})$ (convulsion threshold for Bemegride $\left.{ }^{\circledR}\right)$ (136), and a reduced learning capacity found in rats exposed to $15,000 \mathrm{mg} / \mathrm{m}^{3}(4,000 \mathrm{ppm})$ for $2 \mathrm{~h}$ a day for $60 \mathrm{~d}(59)$.

The odor threshold has been found to be $1.5-3.2 \mathrm{mg} / \mathrm{m}^{3}$ (range for 30 persons) in the case of exposure to pure toluene (53) and $10 \mathrm{mg} / \mathrm{m}^{3}(50 \%)$ in the case of exposure to a commercial product containing $46 \%$ toluene (22).

\section{Peripheral nervous system}

Toxic polyneuropathy has been observed in connection with glue sniffing $(48,127)$. In all cases the glue also contained n-hexane, which must be presumed to be the responsible etiologic factor.

In 38 women working at a factory pro- 
ducing boots and shoes, the findings included significant changes in the reflexes in $16-37 \%$ and reduced grasping capacity of the dominant hand in $29 \%$ (92). The possible existence of $n$-hexane cannot be excluded in this case either.

In exposure tests symptoms of peripheral neurotoxic effect (skin paresthesia, muscular weakness) have been described (103), but no changes in the galvanic skin reflex or provoked vasoconstriction of the fingers has been found (126).

Animal experiments involving exposure to toluene and n-hexane did not support the theory that toluene intensifies the toxic effect of n-hexane on the peripheral nervous system (127). Pure toluene exposures of animals to $7,500 \mathrm{mg} / \mathrm{m}^{3} \quad(2,000$ ppm) for 41 weeks caused effects on this nervous system with a significant increase of the threshold values for the electric stimulation of muscular excitation and the period of latency for muscular response. The increase was not significant after 16 weeks of exposure. Exposure to $750 \mathrm{mg} / \mathrm{m}^{3}$ $(200 \mathrm{ppm})$ for 49 weeks reduced nervous conduction velocity, but exposure to 375 $\mathrm{mg} / \mathrm{m}^{3}$ (100 ppm) did not (90).

\section{Blood and hematopoietic organs}

Until the end of World War II toluene was suspected of having the same hematotoxic effect as benzene. The literature from this early period describes leukocytopenia, shift to the left of the white blood picture, hyperplasia of the bone marrow possibly changing into aplasia, decrease in the number of erythrocytes and hemoglobin percentage, and coagulation defects involving a decreased number of thrombocytes $(4,50,82,83,95,147)$. In other reports $(79,103)$, however, small or no hematological differences have been mentioned. Only a few of these investigations, e.g., von Oettingen et al. (103), discuss possible benzene contamination.

In later clinical reports on exposure to toluene with a low benzene content (below $0.1 \%$ ), the formerly described hematological changes have not been found $(9,37,92,107,125)$.

Case reports continue to be published (11, 12, 26, 55, 64, 72, 86, 89, 108), and also worksite isvestigations $(24,128)$, with findings of bone marrow depression from var- ious types of toluene exposure (worksite, hobby and sniffing). None of these cases deal with exposure to pure toluene. In one investigation 8,000 hematological examinations of printers over a five-year period indicated changes in the erythropoiesis and erythrocyte pattern with an increase in the number of immature cells during the first year of exposure. However, the changes did not progress, and this was interpreted as an adaptive phenomenon. Toluene was mentioned as the only chemical health hazard; possible benzene contamination and other mixed exposure were not mentioned (51).

In a considerable number of toxicologic examinations of animals exposed to toluene with a controlled, low content of benzene, no hematotoxic effect has been detected $(17,22,35,41,42,65,91,122,133$, 150 ). In the case of similar exposure to mixtures of toluene and benzene, however, bone marrow depression has been reported (35). Investigations have also been made of the combined toluene-benzene effect through the measurement of the ${ }^{59} \mathrm{Fe}$ incorporation in erythrocytes of mice (13). Benzene inhibited this incorporation, but toluene did not.

Examinations of leukocytes have shown histochemical changes such as an increased number of leukocyte granules (37, 145) and Mommsen's toxic granules (92), as well as cytochemical changes such as increased activity of acid and alkaline phosphatases and lactate dehydrogenase $(37,145)$. The number of leukocytes has not been found to be affected by the daily oral administration of $0.11 \mathrm{~mol}(10 \mathrm{~g})$ of toluene (16). Histochemical changes with an increased number of leukocyte granules have also been observed in rats $(91,133)$.

In human lymphocytes an increased number of nucleoli and an increased activity of alkaline phosphatases have been observed (37).

\section{Liver}

There are a few reports on acute reversible hepatite after massive exposures to toluene in connection with sniffing $(49,55$, 102). All these cases also involved abuse of other solvents, including alcohol.

The literature studied has not answered the question of whether toluene has an 
irreversible hepatotoxic effect $(18,69)$. However, only a few investigations have been made.

In a group of painters (aircraft industry) the frequency of liver enlargement was three times that observed in a reference group. This finding has not been related to the exposure level (50).

Normal liver function (electrophoresis, serum colloidal stability and galactose tolerance) (107) was observed in 13 rotogravure printers.

In about 50 of 100 rotogravure printers, increased asparate aminotransferase, alanine aminotransferase, glutamate dehydrogenase, and gamma glutamyl transferase values were observed in serum. However, the increase was not significant, because increased values were also observed in a similar number of 100 referents from the same factory (125). The investigation did not consider possible variations in the exposure levels and possible indirect exposure of the reference group.

Another examination (129) of 94 rotogravure printers exposed to $300-1,900$ $\mathrm{mg} / \mathrm{m}^{3}$ on the day of the investigation and a reference group of 30 municipal clerks showed significant reductions in the bilirubin and alkaline phosphatase and a slight, but not significant, increase in serum asparate aminotransferase, alanine aminotransferase, leucinamino-peptidase, and cholinesterase.

A recent examination has shown that exposure of rats to $1,000 \mathrm{ppm}$ for $8 \mathrm{~h}$ a day for $7 \mathrm{~d}$ caused significant increases in serum asparate aminotransferase and alanine aminotransferase (131).

Anomalies in the glucoprotein, serum mucoid and haptoglobin patterns in 53 women (75) and changes in serum iron and serum copper concentration (24) have been interpreted by investigators to indicate, among other things, a hepatotoxic effect of toluene. The summaries did not however report on the purity of the toluene.

By means of histological and histochemical methods and electron microscopy, a dose-related effect has been revealed with respect to the number of mitochondria, nuclear density and nucleus/cytoplasm ratio (144), along with changes in the liver, with signs of increased detoxification ac- tivity in the liver (increased succinate dehydrogenase activity, increased number of mitochondria and a smooth endoplasmic reticulum, decreased Best carmine staining and positive periodic acid Schiff staining) and signs of degeneration of the cells (dilatation of the endoplasmic reticulum and an accumulation of vacuoles as a sign of autophagocytosis). These changes quickly disappeared after exposure. The regenerative property of the liver after hepatectomy was not significantly affected by exposure to toluene (57).

\section{Kidneys}

Acute poisoning of toluene sniffers has caused reversible kidney damage (102); hematuria (88); reversible, type 1 renal tubular acidosis (132); hypokalemia (70, 132 ) and proteinuria (70). Symptoms of muscular weakness, presumably due to hypokalemia, disappeared when the fluidsalt balance had been reestablished $(70$, 132).

Massive exposure to toluene for $18 \mathrm{~h}$ during an occupational accident resulted in kidney failure with oliguria presumably caused by dehydration and myoglobinuria (111). Exposure for a shorter period of time did not show any anomalies in the urine $(84,92)$. Also in a number of animal experiments pathological kidney changes have been observed $(22,35,91)$.

\section{Heart}

A number of experimental exposures of humans to toluene have not shown any effect on pulse, blood pressure and electrocardiographic parameters $(2,103)$. However, other experiments with exposure have shown a tendency towards increased diastolic pressure and a slower pulse rate $(105,126)$. In animal experiments massive doses caused a number of electrocardiographic changes $(96,138)$, and at the same time the heart was sensitized to asphyxia with a possibility of developing 2-1 block (138).

\section{Hormone-producing organs}

Women exposed to mixed solvents containing toluene developed paramenia in some cases $(93,128)$. A case-referent study 
of women working at a boot and shoe factory described a significant increase in the number of cases of paramenia (92). Besides, a pathological picture has been described showing hypofunction of the diencephalon-hypophysis-adrenal cortex system, designated as the diencephalon syndrome, in two workers at a factory producing paints and lacquers (135).

The effect of toluene on the adrenal glands has been examined in experimental exposure of rats $(133,137)$ with reported findings of a reduced organ weight/body weight ratio after long-term exposure. Eosinophil cells in the blood changed initially but gradually normalized. The 11-hydroxycorticosteroid concentration appeared to increase immediately after the onset of exposure and to fall to normal values after long-term exposure. Histologically thicker zona glomerulosa and dark atrophic zona fasciculata and reticularis were observed.

\section{Fetus}

There have been two cases reported in which women working with a solvent containing toluene and trichloroethylene (mean daily dose $372 \mathrm{mg} / \mathrm{kg}$ and 405 $\mathrm{mg} / \mathrm{kg}$, respectively) have born multiply deformed children (34). Exposure of mice to the same solvent (mean daily dose 157 $\mathrm{mg} / \mathrm{kg}$ and $406 \mathrm{mg} / \mathrm{kg}$, respectively) during gestation caused no malformations, but a weight reduction of the fetus at delivery and a decrease in rate and length of gestation, as well as unspecifically described damage to the ova, was observed (34).

\section{Respiratory tract}

An irritative effect on the respiratory tract has been attributed to toluene $(5,18$, 43). In a number of occupational accidents on ships with an estimated short-term exposure to between 37,500 and 112,500 $\mathrm{mg} / \mathrm{m}^{3}(10,000-30,000 \mathrm{ppm})$, there were no complaints of irritation to eyes, throat or lungs among 26 men (84).

\section{Eyes}

Keratitis has been observed in furniture polishers exposed to mixtures of aromatic hydrocarbons, esters (acetates) and alcohols (119). The instillation of solvents onto the eyes of cats and the evaporation of solvents in front of the eyes of furniture polishers has shown that toluene caused the strongest irritation (119). This finding was not confirmed by investigations in which the solvent was instilled directly onto one eye of rabbits. In the latter case only a momentary irritation of the conjunctiva was observed (150). In spray painters exposed to concentrations of up to $4,125 \mathrm{mg} / \mathrm{m}^{3}(1,100 \mathrm{ppm})$ of toluene, no pathological changes were noted in the eyes (50).

Skin

Toluene is a fat solvent and degreases the skin, which may develop toxic contact dermatitis as a consequence $(18,43)$.

\section{Allergic effects}

Allergic effects on the skin have not been observed after toluene exposure. A few investigations attribute disturbances in the immune system, detected in the immunoglobulins and leukocyte agglutinins, to toluene $(77,78)$. However, the exposure also involved benzene. Autoimmune glomerulonephritis has also been attributed to exposure to mixed solvents, but not specifically to toluene (14).

\section{GENOTOXIC EFFECTS}

\section{Mutagenesis in submammalian systems}

No mutagenic effect of toluene in submammalian systems has been observed (27).

\section{Chromosomal aberration}

Cytogenetic investigations of lymphocytes in printers exposed to toluene in 1967 showed no significant increase in the number of chromosomal aberrations when this group was compared with a reference group (36). More recent investigations of 
typographers (in 1977), showed, however, a significantly increased frequency of abnormal lymphocytes and chromosomal breaks but no increment in sister chromatid exchanges (39).

A daily subcutaneous injection of $8.7-$ $11.0 \mathrm{mmol}(0.8-1.0 \mathrm{~g})$ of toluene $/ \mathrm{kg}$ of body weight to animals for $12 \mathrm{~d}$ caused an increased frequency of chromosomal aberrations in comparison with the frequency found in a control group (13.7 and $4.2 \%$, respectively). The same quantitative pattern was observed at benzene concentrations which were four times lower $(28,85)$. The chromosomal aberrations occurred before the hematological changes and lasted longer after exposure (29).

\section{Carcinogenic effect}

The majority of 401 patients suffering from serious diseases (lymphoid leukemia, bone marrow aplasia, myeloid leukemia and myelofibrosis) had been exposed to benzene and toluene (46). Data on the exposure have been obtained from various sources and involve a number of uncertain factors. It is not possible to judge the comparability with the control group.

\section{BIOLOGICAL INDICATORS OF EXPOSURE}

Toluene or its metabolites are found in alveolar air, blood and urine during and after exposure.

During exposure the alveolar air concentration is $25-40 \%$ of the concentration in the inhaled air, all depending on the work load and the duration of exposure (2). The alveolar air concentration follows the changes in the concentration in the inhaled air. After exposure the alveolar air concentration falls in the course of $5 \mathrm{~min}$ to about $10 \%$ of the exposure level. Thereafter the concentration falls at a slower rate (2), corresponding to the two last terms of equation $b$.

During exposure the arterial blood concentration is linearly dependent on the alveolar air concentration in that the distribution coefficient is constant and independent of the work load, 12-17 in vivo (average 15) (2). With exposure to $100 \mathrm{ppm}$ the arterial blood concentration is about $8-22 \mu \mathrm{mol} / 1(0.7-2 \mathrm{mg} / \mathrm{l})$, depending on the work load and the duration of the exposure.

After $30 \mathrm{~min}$ of exposure the venous blood concentration is $30-40 \%$ of the arterial blood concentration at rest, and it increases during the workday with constant exposure. During work the content, expressed as percentage, increases to about $60 \%$ in the course of $20-30 \mathrm{~min}(2)$.

The arterial blood concentration after exposure follows the alveolar air concentration. During the first $10-15 \mathrm{~min}$ after exposure the correlation between the alveolar air, arterial blood and venous blood concentration is high (2). After 30 min the venous blood concentration is still relatively high. The venous blood concentration reflects the absorbed quantity of toluene to some degree.

The hippuric acid content in serum correlates well with the exposure level and the hippuric acid content in urine (7). Ninety-eight rotogravure printers exposed to an average of $101 \mathrm{mg} / \mathrm{m}^{3}(27 \mathrm{ppm})$ of toluene showed mean ( $\pm \mathrm{SD}$ ) levels of $24 \pm 17 \mu \mathrm{mol}(4.3 \pm 3.0 \mathrm{mg})$ of hippuric $\mathrm{acid} / \mathrm{l}$ of serum and $12.3 \pm 8.4 \mathrm{mmol}(2.2 \pm$ $1.5 \mathrm{~g}$ ) of hippuric acid/1 of urine (7). A control group had $11 \pm 6 \mu \mathrm{mol}(1.9 \pm 1.0$ $\mathrm{mg}$ ) of hippuric acid/1 of serum (7).

About $70-75 \%$ of retained toluene is converted to hippuric acid, which is excreted in the urine. Exposure to 375 $\mathrm{mg} / \mathrm{m}^{3}(100 \mathrm{ppm})$ for $8 \mathrm{~h}$ at rest should theoretically result in a total excretion of about $5.6 \mathrm{mmol}(1 \mathrm{~g})$ of hippuric acid. During the performance of light work a total of $11.2-16.8 \mathrm{mmol}(2-3 \mathrm{~g})$ of hippuric acid is excreted $(63,105)$. A control group excreted, on the average, 1.7 mmol (0.3 g) (79). The correlation of absorbed toluene with the excreted quantity of hippuric acid is high (105).

In studies of occupational exposure, it is difficult to procure $24-\mathrm{h}$ urine. Therefore investigators usually collect a specimen at the end of the workday when the excretion of hippuric acid is at its maximum $(104,105)$. A linear correlation has been found between hippuric acid concentration and toluene exposure $(60,63)$ and the toluene concentration in the blood (33). But there are very wide 
variation limits. Regression lines showed approximately $11.2 \mathrm{mmol}(2 \mathrm{~g})$ of hippuric $\mathrm{acid} / \mathrm{g}$ of creatinine at $10.9 \mu \mathrm{mol}(1 \mathrm{mg})$ of toluene/1 of blood (33) and about 16.8 $\mathrm{mmol}(3 \mathrm{~g})$ of hippuric acid/g of creatinine at $100 \mathrm{ppm}$ (105). Correlating the hippuric acid in the urine to exposure to toluene is difficult in that hippuric acid is a normal constituent of urine. It comes from food (especially from fruit and canned food) and from endogenous protein catabolism (phenylalanine). Persons not exposed to toluene excrete about $5.6 \mathrm{mmol}(1 \mathrm{~g})$ of hippuric acid in $24 \mathrm{~h}$, but in this case too there are wide variations from one person to another, from one time of year to another, and from one country to another.

\section{RELATION BETWEEN EXPOSURE, EFFECT AND RESPONSE}

In humans, effects on the CNS, the blood and the hematopoietic organs, the liver and the heart, and in the form of paramenia have been noted. These effects have been observed in the case of shortterm exposures to high concentrations (minutes - few hours) and/or long-term exposures to lower concentrations [workdays - years, up to $1,125 \mathrm{mg} / \mathrm{m}^{3}(300$ ppm)]. Effects only in the case of longterm exposures to massive concentrations or short-term exposures to narcotic and sublethal concentrations have not been considered.

\section{Short-term exposure to high concentrations}

A 3-h exposure to 2,250 and $3,000 \mathrm{mg} / \mathrm{m}^{3}$ $(600$ and $800 \mathrm{ppm})$ has caused extreme fatigue, mental confusion, headache, nausea, and dizziness (103). Exposure to an estimated $18,750-37,500 \mathrm{mg} / \mathrm{m}^{3}(5,000$ $-10,000 \mathrm{ppm}$ ) for $1 \mathrm{~min}$ has caused intoxication and a sensation of respiration trouble followed by unconsciousness (84).

Changes in psychomotor functions have been observed in 12 persons exposed for four successive sequences of $20 \mathrm{~min}$ to 375 , $1,125,1,875$ and $2,625 \mathrm{mg} / \mathrm{m}^{3}(100,300,500$ and $700 \mathrm{ppm}$ ), respectively, in the inhaled air and with analogous control exposure (40). All test parameters (simple reaction time, choice reaction time and two tests in perceptual speed) showed a significant dose-response relation. The simple reaction time was the most sensitive of all, being significantly slower at $1,125 \mathrm{mg} / \mathrm{m}^{3}$ $(300 \mathrm{ppm})$ (8 out of 12 experimental subjects). The choice reaction time was significantly slower at $1,875 \mathrm{mg} / \mathrm{m}^{3} \quad(500$ $\mathrm{ppm}$ ), and the two tests in perceptual speed were significantly poorer at 2,625 $\mathrm{mg} / \mathrm{m}^{3}$ (700 ppm).

\section{Long-term exposure}

Occupational investigations and exposure tests have described neurological symptoms beginning with exposure to 375 $750 \mathrm{mg} / \mathrm{m}^{3}(100-200 \mathrm{ppm})$ over $8 \mathrm{~h}$ and increasing at elevated exposure levels (23, $103,147)$. No statistical or other quantitative evaluation has been made of the dose-response relation.

Reduced reaction time has been reported after exposure involving 23 students to $750 \mathrm{mg} / \mathrm{m}^{3}$ (200 ppm) for $7 \mathrm{~h}(105)$.

Furthermore, changes have been observed in intellectual, emotional, and psychomotor functions and in the personality of various groups of occupationally exposed persons $(54,81,97)$.

Normally, it is not possible to determine the actual exposure level, and often mixed exposures are involved $(54,81)$. An investigation at a rotogravure plant where the printers were primarily exposed to toluene showed "organic psychosyndrome" in $21 \%$ of a group exposed to about 1,125 $\mathrm{mg} / \mathrm{m}^{3}$ (300 ppm) against $40 \%$ of another group exposed to approximately 1,613 $\mathrm{mg} / \mathrm{m}^{3}$ (430 $\left.\mathrm{ppm}\right)$. The average duration of exposure was 18 and 12 years (97).

In five experimental subjects exposed to $750 \mathrm{mg} / \mathrm{m}^{3}(200 \mathrm{ppm})$ for $6 \mathrm{~h}$, increased EEG activity has been observed, but no significant difference was found in a comparison with five controls (126).

Exposure to $161-3,000 \mathrm{mg} / \mathrm{m}^{3} \quad(43-800$ $\mathrm{ppm})$ at a rotogravure printing plant caused an increased number of leukocyte phosphatases (acid and alkaline), lactate dehydrogenase and lymphocyte phospha- 
tase (acid) (37, 145). At $375 \mathrm{mg} / \mathrm{m}^{3}(100$ ppm) (primarily toluene) in the footwear industry an increase in the number of granules in the neutrophilic leukocytes has been observed (92). Pure toluene exposure at the exposure levels mentioned does not produce any other certain changes in hematological parameters.

Rotogravure printers excreting 11.2 $35.8 \mathrm{mmol}(2.0-6.4 \mathrm{~g})$ of hippuric acid/1 of urine and having $0.37-1.76 \mu \mathrm{mol}(33.6$ $-161.5 \mu \mathrm{g}$ ) of toluene $/ 100 \mathrm{~g}$ of blood (corresponding to exposure to about $50-300$ ppm of toluene) had significantly lower values for alkaline phosphatase and serum bilirubin than did a reference group (129). The values, however, were within the normal range. Serum concentration values of asparate aminotransferase, alanine aminotransferase, lactate dehydrogenase, and leucinamine-peptidase at the same exposure level were generally high but not significantly different from the values of the reference group $(125,129)$. Liver enlargement has been observed in painters exposed to $188-4,125 \mathrm{mg} / \mathrm{m}^{\prime \prime}(50-1,100$ $\mathrm{ppm})$ but without mention of any doseresponse relation (50).

Reduced pulse rate has been observed at the end of $6-7 \mathrm{~h}$ of exposure to 750 $\mathrm{mg} / \mathrm{m}^{3}$ (200 ppm) $(105,126)$.

Exposure to about $375 \mathrm{mg} / \mathrm{m}^{3}(100 \mathrm{ppm})$ (essentially toluene) significantly increased the frequency of paramenia in women working at a boot and shoe factory (92). Paramenia caused by mixed exposure has also been mentioned by other authors (93, 128 ), but the exposure concentrations were not specified.

Recent cytogenetic investigations of typographers exposed to an average of $375-750 \mathrm{mg} / \mathrm{m}^{3}(100-200 \mathrm{ppm})$ of toluene for 2-26 years with maximum values of up to about $2,625 \mathrm{mg} / \mathrm{m}^{3}$ (700 $\left.\mathrm{ppm}\right)$ showed chromosomal aberrations (39). There was no dose-response relation established but perhaps a tendency towards more frequent chromosomal aberrations with increasing age. Animal experiments have also shown chromosomal aberrations after subcutaneous doses of about $10 \mathrm{mmol}(0.8-1.0 \mathrm{~g}) / \mathrm{kg}$ for $12 \mathrm{~d}$. These aberrations were reversible $(28,29,85)$.

No certain teratogenic and carcinogenic effects have been observed for toluene $(34,46)$.

\section{DISCUSSION AND EVALUATION}

In the work environment toluene comes into contact with the skin and the respiratory tract primarily in the form of vapors or liquid.

Only very small quantities of toluene vapors are absorbed through the skin. Liquid toluene can be absorbed through the skin, from which further distribution is difficult. The risk of intoxication as a result of skin exposure will, in the case of normal occupational use (cleaning included), be extremely small because toluene quickly diffuses out again after skin contact ceases. Inhalation of toluene vapors is therefore the only real intoxication hazard in the work environment.

On an average $50 \%$ of inhaled toluene vapors is absorbed by the body. The amount absorbed increases as the work load ( $2-3$ times), fat deposits, or inhaled air concentration increases. The absorption may reasonably be described by mathematical models.

Absorbed toluene is distributed through the blood to tissues and organs. With the exception of fatty tissue the concentration in the organs will be one to three times higher than that in the blood. The toluene concentration in fatty tissue is about 80 times higher than that in the blood. This difference also indicates that there may be a considerable concentration in the lipid-rich structures of other organs and tissues, such as nervous tissue in both the peripheral and central nervous system. Accumulation in fatty tissue is very slow, because the supply of blood is small. But nervous tissue is amply provided with blood vessels, and therefore relatively high local concentrations of toluene may quickly accumulate and create symptoms.

Fifteen to twenty percent of inhaled toluene is exhaled unchanged. Besides, small quantities are excreted unchanged in the urine. The rest of absorbed toluene is converted to benzoic acid. Most of this (about $80 \%$ ) is conjugated with glycine and excreted as hippuric acid in the urine. The remaining $20 \%$ of benzoic acid is conjugated with glucuronic acid and excreted in the urine as glucuronide. A very small part of the toluene may possibly be converted to phenolic derivatives and ex- 
creted as glucuronides and sulfates in the urine. Other products and excretions are of no importance. Women eliminate. less toluene through the lungs, while their initial rate of excretion of hippuric acid is higher than that observed in men.

The conversion and excretion of toluene may be affected by food, medicine and some other solvents. The quantity of excreted hippuric acid is increased by food rich in glycine and by medicine inducing the metabolic enzymes of the liver. Persons having no exposure excrete varying quantities of benzoic acid contained in the food consumed. The biotransformation of toluene is inhibited by analogous chemical compounds such as benzene and styrene and by trichloroethylene. This inhibition is reciprocal. In the course of the biotransformation of toluene benzyl radicals and epoxides may be formed.

Exposures of short duration have mainly caused reversible inhibition of the CNS. A stimulating effect has also been observed, however. This effect has been registered as symptoms (such as headache, fatigue, nausea and dizziness) in exposure to $750 \mathrm{mg} / \mathrm{m}^{3}(200 \mathrm{ppm})$ for $8 \mathrm{~h}$, the symptoms increasing with exposure to higher concentrations. However, symptoms have also been detected in some individuals exposed to toluene levels of $188-750 \mathrm{mg} / \mathrm{m}^{3}$ (50-200 ppm) $(103,147)$.

Significantly increased reaction time has been reported after $20 \mathrm{~min}$ of exposure to $375 \mathrm{mg} / \mathrm{m}^{3}$ (100 $\mathrm{ppm}$ ) followed by $20 \mathrm{~min}$ of exposure to $1,125 \mathrm{mg} / \mathrm{m}^{3} \quad(300$ ppm) (40) and after $7 \mathrm{~h}$ of exposure to 750 $\mathrm{mg} / \mathrm{m}^{3}(200 \mathrm{ppm})$ (105). The reaction time was not increased in the case of exposure to $375 \mathrm{mg} / \mathrm{m}^{3}$ (100 ppm) for $20 \mathrm{~min}$. On the basis of this evidence it is not possible to fix any lower limit in respect to the beginning effect of an 8-h exposure to toluene on simple reaction time. At 750 $\mathrm{mg} / \mathrm{m}^{3}$ (200 ppm) a certain effect was detected. Exposure to $750 \mathrm{mg} / \mathrm{m}^{3}$ for $6 \mathrm{~h}$ resulted in increased nonsignificant EEG activity (126).

As is the case with other solvents, toluene exposure of long duration may presumably cause irreversible damage to the CNS with a reduction in intellectual, psychomotor and emotional functions often included under designations such as psychoorganic syndrome and presenile demens. This assumption is primarily based on a number of case reports and on some comprehensive occupational investigations involving case-referent studies $(49$, 55, 70, 74, 97, 118). Neurophysiological and behavioral examinations of animals in toxicologic studies made in recent years support this view.

Such an effect on the CNS has been observed in 21 and $40 \%$ of groups exposed, at the time of investigation, to an average of 1,125 and $1,613 \mathrm{mg} / \mathrm{m}^{3}$ ( 300 and 430 $\mathrm{ppm}$ ) for average periods of 18 and 12 years, respectively (97). The same effect may be detected at even lower exposure levels, but the investigations made are not suitable for establishing a nonresponse level $(54,81)$.

There are still many uncertain factors because the basis of human diagnosis is not very specific and because it is very seldom possible to determine exposure levels in a satisfactory way.

Toluene has not been proved to cause irreversible damage to the peripheral nervous system. n-Hexane and ethyl alcohol alone may explain the findings of polyneuropathy mentioned in connection with toluene exposure.

In the literature there is general agreement that toluene does not have the hematotoxic properties of benzene. Besides, it has not at all been possible to detect any hematotoxic effect in a number of wellcontrolled occupational investigations and in animal experiments using pure toluene. A number of investigations indicate, however, that toluene affects the morphology of the leukocytes. What these findings mean has not been fully clarified. Furthermore, there is still some uncertainty as to the effect of contamination with small coricentrations of benzene. The effect on the morphology of the leukocytes has been reported with certainty in the case of exposures of longer duration to $375 \mathrm{mg} / \mathrm{m}^{3}$ $(100 \mathrm{ppm})$ (glue primarily containing toluene) (92). Effects on leukocyte and lymphocyte enzymes, as well as lymphocyte morphology, have also been observed in the case of exposures in the range of $161-3,000 \mathrm{mg} / \mathrm{m}^{3} \quad(43-800 \mathrm{ppm})$ (pure toluene) $(37,145)$.

Reversible toxic hepatite has been reported after exposure to large quantities of toluene. No reports are available indi- 
cating that toluene may cause irreversible damage to the liver.

In rats injected intraperitoneally with about $1 \mathrm{mmol}(0.1 \mathrm{ml})$ of toluene $/ 100 \mathrm{~g}$ of body weight for $12 \mathrm{~d}$, increased biotransformation activity in the cells of the liver, and signs of cellular degeneration have been observed. These changes are reversible and quickly normalize after exposure (144).

Reports on the hepatotoxic effect of occupational exposure to toluene are inconsistent both in respect to quite normal findings of concentrations in the enzymes of the liver and in respect to increases in comparisons with reference groups. This inconsistency may be due to variations in sampling times and alcohol consumption.

The effect of toluene on liver enzymes and serum bilirubin concentrations has been observed in the case of excretion of hippuric acid of $11.2-35.8 \mathrm{mmol}(2.0-$ $6.4 \mathrm{~g}) / \mathrm{l}$ of urine or $0.37-1.76 \mu \mathrm{mol}(33.6-$ $161.5 \mu \mathrm{g})$ of toluene $/ 100 \mathrm{~g}$ of blood [corresponding to an exposure level of about $\left.188-1,125 \mathrm{mg} / \mathrm{m}^{3}(50-300 \mathrm{ppm})\right](129)$.

Massive and more-or-less long-term exposure to toluene has caused reversible damage to the kidneys, possibly by affecting the epithelium in tubuli renales with consequent disturbances in their transport functions. Lower concentrations do not seem, however, to cause clinically detectable effects on the kidney.

There are few and inconsistent reports available on the effect of toluene on the heart, determined by pulse rate and blood pressure of humans. Seven hours of experimental exposure to $750 \mathrm{mg} / \mathrm{m}^{3} \quad(200$ ppm) have produced a reduced pulse rate and a possible effect on diastolic pressure $(105,126)$.

At $375 \mathrm{mg} / \mathrm{m}^{3}$ (100 $\left.\mathrm{ppm}\right)$ (glue primarily containing toluene) a significantly increased frequency of paramenia has been observed (92). Other investigations mention similar findings but without indicating the exposure level and possible contamination of toluene with benzene.

Experimental examinations of animals and some clinical observations indicate that toluene has an inhibitory effect on diencephalon, on the hypophysis, and on the adrenal glands; but only a few reports are available.

Toluene causes only minor irritation of the respiratory tract. High concentrations of toluene may slightly irritate the eyes. Neither experience from occupational accidents involving splashes of pure toluene onto the eyes nor experimental examinations of animals indicate that toluene can cause permanent eye damage.

There is inconsistent information available on the genotoxic effect of toluene on human cells. Average concentrations of up to about $1,039 \mathrm{mg} / \mathrm{m}^{3}$ ( $277 \mathrm{ppm}$ ) of toluene, with peak values of up to about $3,090 \mathrm{mg} / \mathrm{m}^{3}$ (824 $\left.\mathrm{ppm}\right)$, did not result in chromosomal aberrations in the case of exposure for 3-15 years (36), but exposure for 2-26 years did (39).

The most sensitive indicators of toluene action are a number of symptoms in the CNS and in the psychomotor functions. Besides, it has been stated that like a number of other solvents toluene may cause chromosomal aberrations, probably reversible, in human lymphocytes. Paramenia has also been mentioned. Finally, it has been observed that toluene affects certain blood cells and their enzymes, as well as liver cells and the liver enzymes in serum. The clinical importance of these findings has not been clarified.

A number of the reported effects have been observed at high exposure levels. Very few observations have been made at exposure levels of $0-375 \mathrm{mg} / \mathrm{m}^{\prime \prime}(0-100$ $\mathrm{ppm})$. There are no reports on the doseresponse relationship over an 8 -h workday at these concentration levels.

\section{REFERENCES}

1. ASTRAND, I. Uptake of solvents in the blood and tissues of man: A review. Scand. j. work environ. \& health 1 (1975) $199-218$

2. ÅSTRAND, I., EHRNER-SAMUEL, H., KILBOM, $\AA$. and ÖVRUM, P. Toluene exposure: I. Concentration in alveolar air and blood at rest and during exercise. Work environ. health 9 (1972) 119-130.

3. ABOU-EL-MAKAREM, M. M., MILLBURN, P., SMITH, R. L. and WILLIAMS, R. T. Biliary excretion of foreign compounds: Benzene and its derivatives in the rat. Biochem. $j .105$ (1967) 1269-1274.

4. ADLER-HERZMARK, J. Periodische Untersuchungen von Arbeitern: III. Periodische Untersuchungen von Wiener Arbeitern, die mit benzol-, toluol- und xylolhältigen Materialien beschäftigt sind. Arch. Gewerbepathol. Gewerbehyg. 4 (1933) 486-490. 
5. ANDERSEN, P. and KAADA, B. R. The electroencephalogram in poisoning by laquer thinner (butyl acetate and toluene). Acta pharmacol. toxicol. 9 (1953) 125130.

6. ANDREWS, L. S., LEE, E. W., WITMER, C. M., KOCSIS, J. J. and SNYDER, R. Effects of toluene on the metabolism: Disposition and hemopoietic toxicity of ${ }^{3} \mathrm{H}-$ benzene. Biochem. pharmacol. 26 (1977) $293-300$.

7. ANGERER, J., KASSEBART, V., SZADKOWSKI, D. and LEHNERT, G. Chronische Lösungsmittelbelastung am Arbeitsplatz: III. Eine gaschromatographische Methode zur Bestimmung von Hippursäure im Serum. Int. Arch. Arbeitsmed. 34 (1975) 199-207.

8. ARBETARSKYDDSVERKET. Nordiska exspertgruppen för gräensvärde dokumentation: 2. Toluen (Arbete och hälsa no. 1979:5). Stockholm 1979. 63 p.

9. BANFER, W. Untersuchungen über Einwirkung von Reintoluol auf das Blutbild von Druckern und Hilfsarbeitern im Tiefdruck. Zentralbl. Arbeitsmed. Arbeitsschutz 11 (1961) 35-40.

10. BAKKE, O. M. and SCHELINE, R. R. Hydroxylation of aromatic hydrocarbons in the rat. Toxicol. appl. pharmacol. 16 (1970) $691-700$

11. BARBACKI, M. Intossicazione da miscela di vapori di benzene, toluene e benzina in otto bambini. Minerva pediatr. 23 (1971) $507-510$

12. BARBACKI, M. A trial of assessment of the effects of butapren glue vapours on the health state of children from families doing cottage work in leather industry (in Polish with English summary). Pediatr. pol. 46 (1971) 931-936.

13. BARDODEJ, Z. Beurteilung der Gefährdung durch Toluol in der Industrie mittels der Hippursäurebestimmung im Harn. Arbeitsmed. Sozialmed. Arbeitshyg. 3 (1968) 254

14. BEIRNE, G. J. and BRENNAN, J. T. Glomerulonephritis associated with hydrocarbon solvents: Mediated by antiglomerular basement membrane antibody. Arch. environ. health 25 (1972) 365-369.

15. BONCZOS, L., BUGYI, $B$. and ZAMBOLT, K. Beitrag zur Neurotoxizität des industriellen Toluols im Strassenverkehr. Verk.-med. 20 (1973) 469-470.

16. BRAIER, L. Traitement des leucoses chroniques par le benzène et ses homoloques: Le rôle des donneurs de méthyles. Le sang 24 (1953) 603-612.

17. BRAIER, L. A comparative study of isocyclic hydrocarbons in animals and in man. Haematologica 58 (1973) 491-500.

18. BROWNING, E. Toxicity and metabolism of industrial solvents. Elsevier Publ. Co., Amsterdam 1965, pp. 66-76.

19. BURINGH, E., BROEKMAN, J. VAN MOURIK, OSKAM, N. and IJLAND, M. Invloed van toluol op de gezondheid van arbeiders in rotatiediepdruk. Tijdschr. soc. geneesk. 52 (1974) 13-18.
20. CAPELLINI, A. and ALESSIO, L. L'eliminazione urinaria di acido ippurico in operai esposti a toluolo. Med. lav. 62 (1971) $196-201$.

21. CARLSSON, A. and LINDQVIST, T. Exposure of animals and man to toluene. Scand. $j$. work environ. \& health 3 (1977) 135-143.

22. CARPENTER, C. P., GEARY, D. L. JR., MYERS, R. C., NACHREINER, D. J., SULLIVAN, L. J. and KING, J. M. Petroleum hydrocarbon toxicity studies: XIII. Animal and human response to vapors of toluene concentrate. Toxicol. appl. pharmacol. 36 (1976) 473-490.

23. CARPENTER, C. P., SHAFFER, C. B. WEIL, C. S. and SMYTH, H. F. JR. Studies on the inhalation of 1:3-butadiene; with a comparison of its narcotic effect with benzol, toluol, and styrene, and a note on the elimination of styrene by the human. J. ind. hyg. toxicol. 26 (1944) $69-78$.

24. CIESLIŃSKA, A., KOWAL-GIERCZAK, B., KUCZYNSSKA-SEKIETA, K., MAEOLEPSZY, J. and WRZYSZCS, M. Serum iron and copper levels in patients exposed chronically to toluene (In Polish with English summary). Pol. tyg. lek. 24 (1969) $1848-1850$

25. CONNEY, A. H. Pharmacological implications of microsomal enzyme induction. Pharmacol. rev. 19 (1967) 317-366.

26. CURTES, J.-P., LE MAREC, M., GUÉRIN, D. and MICHAUX, P. Leucémie myéloïde chronique d'origine toxique. J. eur. toxicol. 6 (1973) 306-308.

27. DEAN, B. J. Genetic toxicology of benzene, toluene, xylenes and phenols. $M u$ tat. res. 47 (1978) 75-97.

28. DOBROKHOTOV, V. B. Bensens och toluens mutagena effekter under experimentella förhållanden (Swedish translation from Russian). Gig. sanit. 37 (1972) $36-39$.

29. DOBROKHOTOV, V. B. and ENIKEEV, M. I. The mutagenic action of benzol, toluol and a mixture of these hydrocarbons in a chronic test (in Russian with English summary). Gig. sanit. 42 (1977) $32-34$.

30. DODDS, J. and SANTOSTEFANO, S. A comparison of the cognitive functioning of glue-sniffers and nonsniffers. J. pediatr. 64 (1964) 565-569.

31. DUTKIEWICZ, T. and TYRAS, H. The quantitative estimation of toluene skin absorption in man. Int. Arch. Gewerbepathol. Gewerbehyg. 24 (1968) 253-257.

32. EGLE, J. L. JR. and GOCHBERG, B. J. Respiratory retention of inhaled toluene and benzene in the dog. J. toxicol. environ. health 1 (1976) 531-538.

33. ENGSTROMM, K., HUSMAN, K. and RANTANEN, J. Measurement of toluene and xylene metabolites by gas chromatography. Int. arch. occup. environ. health 36 (1976) $153-160$.

34. EULER, H. H. Tierexperimentelle Untersuchung einer Industrie-Noxe. Arch. Gynaekol. 204 (1967) 258-259.

35. FABRE, R., TRUHAUT, R., LAHAM, S. 
and PÉRON, M. Recherches toxicologiques sur les solvants de remplacement de benzène, II. Étude du toluène. Arch. mal. prof. med. trav. secur. soc. 16 (1955) 197215.

36. FORNI, A., PACIFICO, E. and LIMONTA, A. Chromosome studies in workers exposed to benzene or toluene or both. Arch. environ. health 22 (1971) 373-378.

37. FRIBORSKÁ, A. Some cytochemical findings in the peripheral white blood cells in workers exposed to toluene. Folia haematol. (Leipzig) 99 (1973) 233-237.

38. FRIDLYAND, I. B. Bilding av fenol ur bensen och några av dess homologer i djurorganismen (Swedish translation from Russian). Farmakol. toksikol. (Moscow) 33 (1970) $499-501$.

39. FUNES-CRAVIOTO, F., KOLMODINHEDMAN, B., LINDSTEN, J., NORDENSKJÖLD, M., ZAPATA-GAYON, C., LAMBERT, B., NORBERG, E., OLIN, R. and SWENSSON, $\AA$. Chromosome aberrations and sister-chromatid exchange in workers in chemical laboratories and a rotoprinting factory and in children of women laboratory workers. Lancet 2 (1977) 322-325

40. GAMBERALE, F, and HULTENGREN, M. Toluene exposure: II. Psychophysiological functions. Work environ. health 9 (1972) $131-139$.

41. GERARDE, H. W. Toxicological studies on hydrocarbons. II. A comparative study of the effect of benzene and certain mono-n-alkylbenzenes on hemopoiesis and bone marrow metabolism in rats. Arch. ind. health 13 (1956) 468-474.

42. GERARDE, H. W. Toxicological studies on hydrocarbons: III. The biomorphology of the phenylalkanes and phenylalkenes. Arch. ind. health 19 (1959) 403-418.

43. GFRARDE, H. W. Toxicology and biochemistry of aromatic hydrocarbons. Elsevier Publishing Co., Amsterdam 1960, pp. $141-150$.

44. GERARDE, H. W. and AHLSTROM, D. B. Toxicologic studies on hydrocarbons: XI. Influence of dose on the metabolism of mono-n-alkyl derivatives of benzene. Toxicol. appl. pharmacol. 9 (1966) 185190.

45. GILETTE, J. R. Side chain oxidation of alkyl substituted ring compounds: I. Enzymatic oxidation of p-nitrotoluene. $J$. biol. chem. 234 (1959) 139-143.

46. GIRARD, R., TOLOT, F. and BOURRET, J. Hydrocarbures benzéniques et hémopathies graves. Arch. mal. prof. med. trav. secur. soc. 31 (1970) 625-636

47. GOLDSTEIN, A., ARONOW, L. and KALMAN, S. M. Principles of drug action: The basis of pharmacology (2nd ed.). Wiley International Edition. John Wiley \& Sons, Inc., New York, NY 1974, p. 347.

48. GOTO, I., MATSUMURA, M., INOUE, N., MURAI, Y., SHIDA, K., SANTA, T. and KUROIWA, Y. Toxic polyneuropathy due to glue sniffing. $J$. neurol. neurosurg. psychiatry 37 (1974) 848-853.

49. GRABSKI, D. A. Toluene sniffing pro- ducing cerebellar degeneration. Am. j. psychiatry 118 (1961) 461-462.

50. GREENBURG, L., MAYERS, M. R., HEIMANN, H. and MOSKOWITZ, S. The effects of exposure to toluene in industry. J. am. med. assoc. 118 (1942) 573-578.

51. GRIBOVA, I. A., ZORINA, L. A. and SORKINA, N. S. Blodsystemets tillstånd hos arbetare som har kontakt med toluen (Swedish translation from Russian). Gig. tr. prof. zabol. 19 (1975) 6-10.

52. GUILLEMIN, M., MURSET, J. C., LOB, M. and RIQUEZ, J. Simple method to determine the efficiency of a cream used for skin protection against solvents. $\mathrm{Br}$. j. ind. med. 31 (1974) $310-316$.

53. GUSEV, I. S. Reflective effects of microconcentrations of benzene, toluene, $x y-$ lene and their comparative assessment (English translation from Russian). Gig. sanit. 30 (1965) $331-336$.

54. HÄNNINEN, H., ESKELINEN, L., HUSMAN, $K$. and NURMINEN, M. Behavioral effects of long-term exposure to a mixture of organic solvents. Scand. j. work environ. \& health 2 (1976) 240-255.

55. HEUSER, M. Toluolsucht. Med. klin. 63 (1968) $1888-1890$.

56. HOOK, G. E. R. and SMITH, J. N. Oxidation of methyl groups by grass grubs and vertebrate liver enzymes. Biochem. $j$. 102 (1967) 504-510.

57. HUDÁK, A., BORS, Z., UNGVÁRY, G. and FOLLY, G. Reversibility and interaction with hepatic regeneration of toluene induced liver injury. Acta morphol. acad. sci. hung. 24 (1976) 153-166.

58. IKEDA, M. Reciprocal metabolic inhibition of toluene and trichloroethylene in vivo and in vitro. Int. Arch. Arbeitsmed. 33 (1974) 125-130.

59. IKEDA, T. and MIYAKE, H. Decreased learning in rats following repeated exposure to toluene: Preliminary report. Toxicol. lett. 1 (1978) 235-239.

60. IKEDA, M. and OHTSUJI, H. Significance of urinary hippuric acid determination as an index of toluene exposure. $\mathrm{Br} . j$. ind. med. 26 (1969) 244-246.

61. IKEDA, M. and OHTSUJI, H. Phenobarbital-induced protection against toxicity of toluene and benzene in the rat. Toxicol. appl. pharmacol. 20 (1971) 30-43.

62. IKEDA, M., OHTSUJI, H. and IMAMURA, T. In vivo suppression of benzene and styrene oxidation by coadministered toluene in rats and effects of phenobarbital. Xenobiotica 2 (1972) 101106.

63. IMAMURA, T. and IKEDA, M. Lower fiducial limit of urinary metabolite level as an index of excessive exposure to industrial chemicals. $B r . j$. ind. med. 30 (1973) $289-292$.

64. ISAGER, H. Fatal knoglemarvsaplasi efter indånding af dampe fra toluenholdig lim. Ugeskr. laeg. 137 (1975) 2197-2198.

65. JENKINS, L. J. JR., JONES, R. A. and SIEGEL, J. Long-term inhalation screening studies of benzene, toluene, o-xylene, and cumene on experimental animals. 
Toxicol. appl. pharmacol. 16 (1970) 818823.

66. JERINA, D. M. and DALY, J. W. Arene oxides: A new aspect of drug metabolism. Science 185 (1974) 573-582.

67. JERINA, D. M., DALY, J. W. and WIT$\mathrm{KOP}, \mathrm{B}$. The role of arene oxide-oxepin systems in the metabolism of aromatic substrates: II. Synthesis of 3,4-toluene4-"H oxide and subsequent "NIH shift" to 4-hydroxytoluene-3-2 H. J. am. chem. soc. 90 (1968) 6523-6525.

68. KATO, R., VASSANELLI, P., FRONTINO, G. and CHIESARA, E. Variation in the activity of liver microsomal drug metabolizing enzymes in rats in relation to age. Biochem. pharmacol. 13 (1964) 1037-1051.

69. KAZANTZIS, G. Some aspects of hepatic pathology Ann. occup. hyg. 9 (1966) 243248.

70. KELLY, T. W. Prolonged cerebellar dysfunction associated with paint-sniffing. Pediatrics 56 (1975) 605-606.

71. KIMURA, E. T., EBERT, D. M. and DODGE, P. W. Acute toxicity and limits of solvent residue for sixteen organic solvents. Toxicol. appl. pharmacol. 19 (1971) 699--704.

72. KLAVIS, G. and WILLE, F. Schwierigkeiten bei der Beurteilung von Knochenmarksschäden nach Toluoleinwirkung. Zentralbl. Arbeitsmed. Arbeitsschutz 17 (1967) $174-176$.

73. KNOOP, F. and GEHRKE, M. Über die Oxydation von Essigsäure, Aceton und Toluol. I. Über die Oxydation von Essigsäure und Aceton mit Hydroperoxyd II. Uber die Oxydation des Toluols im Tierkörper. Hoppe Seylers Z. Physiol. Chem. 146 (1925) 63-71.

74. KNOX, J. W. and NELSON, J. R. Permanent encephalopathy from toluene inhalation. N. engl. j. med. 275 (1966) 14941496.

75. KOWAL-GIERCZAK, B., KUCZYÑSKASEKIETA, K., CIESLIŃSKA, A., WRZYSZCZ, M. and MALOLEPSZY, J. Certain biochemical tests in subjects with occupational exposure to toluene (in Polish with English summary). Pol. tyg. lek. 24 (1969) 1682-1685.

76. LAHAM, S. Metabolism of industrial solvents. Ind. med. 39 (1970) 237-240.

77. LANGE, A., SMOLIK, R., ZATOŃSKI, W. and GLAZMAN, H. Leukocyte agglutinins in workers exposed to benzene, toluene and xylene. Int. Arch. Arbeitsmed. 31 (1973) $45-50$.

78. LANGE, A., SMOLIK, R., ZATOŃSKI, W. and SZYMAŃSKA, J. Serum immunoglobulin levels in workers exposed to benzene, toluene and xylene. Int. Arch. Arbeitsmed. 31 (1973) 37-44.

79. LIND, G. Über die Bedeutung von Blutveränderungen bei Spritzlackierern. Arch. Gewerbepathol. Gewerbehyg. 9 (1939) 141 $-166$.

80. LINDQVIST, T. Fördelningskoefficienterna blod/luft och vatten/luft för några vanliga lösningsmedel (Arbete och hälsa no. 8). Arbetarskyddsverket, Stockholm 1977. $15 \mathrm{p}$.

81. LINDSTRÖM, K. Psychological performances of workers exposed to various solvents. Work environ. health 10 (1973) 151 -155 .

82. LITZNER, S. and EDLICH, W. Über Toluolschädigungen bei der Herstellung von Tiefdruckfarben. Med. Klin. 28 (1932) $1741-1743$.

83. LOB, M. L'intoxication chronique au toluol et au xylol et ses répercussions sur les organes hématopoiétiques. Schweiz. Med. Wochenschr. 82 (1952) 1125-1126.

84. LONGLEY, E. O., JONES, A. T., WELCH, $R$. and LOMAEV, $O$. Two acute toluene episodes in merchant ships. Arch. environ. health 14 (1967) 481-487.

85. LYAPKALO, A. A. Bensens och toluens genetiska aktivitet (Swedish translation from Russian). Gig. tr. prof. zabol. 17 (1973) $24-28$.

86. MACURA, M. A case of hypoplastic anaemia and liver damage as a consequence of chronic benzene and toluene intoxication (in Polish with English summary). Przegl. lek. 8 (1967) 642-644.

87. MASRY, A. M. EL, SMITH, J. N. and WILLIAMS, R. T. Studies in detoxication. 69. The metabolism of alkyl-benzenes: n-Propyl-benzene and n-butylbenzene with further observations on ethyl-benzene. Biochem. j. 64 (1956) 50 -56 .

88. MASSENGALE, O. N., GLASER, H. H. LE LIEVRE, R. E., DODDS, M. J. B. and KLOCK, M. E. Physical and psychologic factors in glue sniffing. $N$. engl. $j$. med. 269 (1963) $1340-1344$.

89. MATHIES, V. Toluolsucht. Med. Klin. 65 (1970) $463-464$

90. MATSUMOTO, T. Experimental studies on the chronic toluene poisoning: 2 . Electrophysiological changes of peripheral neuromuscular function in the rats exposed to toluene (in Japanese with English summary). Jpn. j. ind. health 13 (1971) 399-407.

91. MATSUMOTO, T., TAKEUCHI, Y., TANAKA, T. and MAEDA, K. Experimental studies on the chronic toluene poisoning: 3. Effects of toluene exposure on blood and organs in the rats (in Japanese with English summary). Jpn. j. ind. health 13 (1971) $501-506$.

92. MATSUSHITA, T., ARIMATSU, Y., UEDA, A., SATOH, K. and NOMURA, S. Hematological and neuro-muscular response of workers exposed to low concentration of toluene vapor. Ind. health 13 (1975) 115-121.

93. MICHON, S. Disturbances of menstruation in women working in an atmosphere polluted with aromatic hydrocarbons (in Polish with English summary). Pol. tyg. lek. 20 (1965) 1648-1649.

94. MITOMA, C., POSNER, H. S., REITZ, H. C. and UDENFRIEND, S. Enzymatic hydroxylation of aromatic compounds. Arch. biochem. biophys. 61 (1956) 431-441.

95. MOESCHLIN, S. Klinik und Therapie der 
Vergiftungen (4. Aufl.). Georg Thieme Verlag, Stuttgart 1965. 750 p.

96. MORVAI, V., HUDÁK, A., UNGVÁRY, G. and VARGA, B. ECG changes in benzene, toluene and xylene poisoned rats. Acta med. acad. sci. hung. 33 (1976) 275 -286 .

97. MUNCHINGER, R. Der Nachweis zentralnervöser Störungen bei Lösungsmittelexponierten Arbeitern. In: 14. international congress of occupational health (Madrid, September 16-21, 1963) (vol. 2) Excerpta Medica Foundation, Amsterdam 1964 , pp. $687-689$.

98. NATIONAL INSTITUTE FOR OCCUPATIONAL SAFETY AND HEALTH Criteria for a recommended standard: Occupational exposure to toluene. Cincinnati, $\mathrm{OH}$ 1973. $98 \mathrm{p}$.

99. NOMIYAMA, $K$. and NOMIYAMA, $H$. Respiratory retention, uptake and excretion of organic solvents in man: Benzene, toluene, n-hexane, trichloroethylene, acetone, ethyl acetate and ethyl alcohol. Int. Arch. Arbeitsmed. 32 (1974) 75-83.

100. NOMIYAMA, $K$. and NOMIYAMA, $H$. Respiratory elimination of organic solvents in man: Benzene, toluene, n-hexane, trichloroethylene, acetone, ethyl acetate and ethyl alcohol. Int. Arch. Arbeitsmed. 32 (1974) 85-91.

101. NOMIYAMA, $K$. and NOMIYAMA, $H$. Three fatal cases of thinner-sniffing, and experimental exposure to toluene in human and animals. Int. arch. occup. environ. health 41 (1978) 55-64.

102. O'BRIEN, E. T., YEOMAN, W. B. and HOBBY, J. A. E. Hepatorenal damage from toluene in a "Glue sniffer." $\mathrm{Br}$. med. j. 2 (1971) $29-30$.

103. OETTINGEN, W. F. VON, NEAL, P. A. and DONAHUE, D. D. The toxicity and potential dangers of toluene. J. am. med. assoc. 118 (1942) 579-584.

104. OGATA, M., NAGAO, I. and TOMOKUNI, K. Urinary hippuric acid excretion in persons exposed to various concentrations of toluene in an exposure chamber. Jpn. j. ind. health 10 (1968) 64-74.

105. OGATA, M., TOMOKUNI, K. and TAKATSUKA, Y. Urinary excretion of hippuric acid and $m$ - or p-methyl hippuric acid in the urine of persons exposed to vapours of toluene and $m$ - or p-xylene as a test of exposure. Br. j. ind. med. 27 (1970) 43-50.

106. PAPPER, E. M. and KITZ, R. J. Uptake and distribution of anesthetic agents. The Blakiston Division, McGraw-Hill Book Co., Inc., New York, NY 1963, pp. 72-87.

107. PARMEGGIANI, L. and SASSI, C. Sul rischio professionale da toluolo: Indagini ambientali e ricerche cliniche nella intossicazione cronica. Med. lav. 45 (1954) $574-583$

108. PINKHAS, J., COHEN, I., KRUGLAK, J. and DE VRIES, A. Hobby-induced factor VII deficiency. Haemostasis 1 (1972) 52 -54 .

109. PIOTROWSKI, J. Quantitative estimate of the absorption of toluene in people (in
Czechoslovakian with English summary). Med. pr. 18 (1967) 213-223.

110. PYYKKÖ, K., TÄHTI, $H$. and VAPAATALO, $\mathrm{H}$. Toluene concentrations in various tissues of rats after inhalation and oral administration. Arch. toxicol. 38 (1977) $169-176$.

111. REISIN, E., TEICHER, A., JAFFE, R. and ELIAHOU, H. E. Myoglobinuria and renal failure in toluene poisoning. $B r . j$. ind. med. 32 (1975) 163-168.

112. RIIHIMÄKI, V. and PFÄFFLI, P. Percutaneous absorption of solvent vapors in man. Scand. j. work environ. \& health 4 (1978) $73-85$.

113. SATO, A. and FUJIWARA, Y. Elimination of inhaled benzene and toluene in man. Jpn. j. ind. health 14 (1972) 224225.

114. SATO, A., FUJIWARA, Y. and HIROSAWA, K. Solubility of benzene, toluene and $\mathrm{m}$-xylene in blood (in Japanese with English summary). Jpn. $j$. ind. health 14 (1972) 3 -8.

115. SATO, A. and NAKAJIMA, T. Vatten/ luft, blod/luft, olja/luft, olja/vatten och olja/blod fördelningskoefficienter av några aromatiska kolväten (Swedish trans'lation from Japanese). Jpn. $j$. ind. health 19 (1977) 132-133.

116. SATO, A. and NAKAJIMA, T. Differences following skin or inhalation exposure in the absorption and excretion kinetics of trichloroethylene and toluene. Br. j. ind. med. 35 (1978) 43-49.

117. SATO, A., NAKAJIMA, T., FUJIWARA, Y. and HIROSAWA, K. Pharmacokinetics of benzene and toluene. Int. Arch. Arbeitsmed. 33 (1974) 169-182.

118. SATRAN, R. and DODSON, V. N. Toluene habituation: Report of a case. $N$. engl. $j$. med. 268 (1963) 719-721.

119. SCHMID, E. Die Augenhornhauterkrankung der Möbelpolierer. Arch. Gewerbepathol. Gewerbehyg. 15 (1956) 37-44.

120. SHERWOOD, R. J. Ostwald solubility coefficients of some industrially important substances. Br. j. ind. med. 33 (1976) $106-107$.

121. SMITH, J. N., SMITHIES, R. H. and WILLIAMS, R. T. Studies in detoxication: 55. The metabolism of alkylbenzenes. (a) Glucuronic acid excretion following the administration of alkylbenzenes. (b) Elimination of toluene in the expired air of rabbits. Biochem. j. 56 (1954) 317-320.

122. SPECK, B. and MOESCHLIN, S. Die Wirkung von Toluol, Xylol, Chroramphenicol und Thiouracil auf das Knochenmark. Experimentelle autoradiographische Studien mit ${ }^{3} \mathrm{H}-\mathrm{Thymidin}$. Schweiz. Med. Wochenschr. 98 (1968) 1684-1686.

123. SRBOVA, J. and TEISINGER, J. Absorption and elimination of toluene in man (in Czechoslovakian with English summary). Prac. lek. 4 (1952) 41-47.

124. SRBOVA, J. and TEISINGER, J. On the metabolismus of toluene (in Czechoslovakian with English summary). Prac. lek. 5 (1953) 259-263.

125. SUHR, E., HAUF, R. and PELZER, E. 
Vergleichende Untersuchungen über den Gesundheitszustand toluolexponierter Tiefdrucker. Gesellschaft zur Förderung des Tiefdrucks e.V., Wiesbaden 1976. 99 p.

126. SUZUKI, $H$. Autonomic nervous responses to experimental toluene exposure in humans (in Japanese with English summary. Jpn. j. ind. health 15 (1973) $379-384$

127. SUZUKI, T., SHIMBO, S., NISHITANI, H., OGA, T., IMAMURA, T. and IKEDA, M. Muscular atrophy due to glue sniffing. Int. Arch. Arbeitsmed. 33 (1974) 115-123.

128. SYRAVADKO, O. N., SKORMIN. V. F., PRONKOVA, E. N., SORKINA, N. S., IZYUMOVA, A. S., GRIBOVA, I. A. and POPOVA, A. F. The influence of working conditions on the health status and some specific functions of women handling white spirit (in Russian with English summary). Gig. tr. prof. zabol. 17 (1973) $5-8$.

129. SZADKOWSKI, D., PEIFFER, D. and ANGERER, J. Beurteiling einer beruflichen Toluolexposition hinsichtlich ihrer hepatotoxischen Relevanz. Med. Monatsschr. 30 (1976) 25-28.

130. SZADKOWSKI, D., PETT, R., ANGERER, J., MANZ, A. and LEHNERT, G. Chronische Lösungsmittelbelastung am Arbeitsplatz: II. Schadstoffspiegel im Blut und Metabolitten Elimination im Harn in ihrer Bedeutung als Überwachungskriterien bei toluolexponierten Tiefdruckern. Int. Arch. Arbeitsmed. 31 (1973) 265276.

131. TÄHTI, H., RUUSKA, J. and VAPAATALO, H. Toluene toxicity studies on rats after one week inhalation exposure. Acta pharmacol. toxicol. 41 (1977): suppl. 4, 78.

132. TAHER, S., ANDERSON, R. J., MC CARTNEY, R., POPOVTZER, M. M. and SCHRIER, R. W. Renal tubular acidosis associated with toluene "sniffing." $N$. engl. j. med. 290 (1974) 765-768.

133. TAKEUCHI, Y. Experimental studies on the toluene poisoning - Chiefly on the findings of peripheral blood and adrenal gland. Ind. health 7 (1969) $31-45$.

134. TAKEUCHI, Y. and HISANAGA, N. The neurotoxicity of toluene: EEG changes in rats exposed to various concentrations. Br. j. ind. med. 34 (1977) 314-324.

135. TAKEUCHI, Y., NISHIZAKI, T., TAKAGI, S. and MABUSHI, C. Diencephalic syndrome in two workers exposed mainly to toluene vapor (in Japanese with English summary). Jpn. j. ind. health 14 (1972) $563-571$.

136. TAKEUCHI, Y. and SUZUKI, H. Change of convulsion threshold in the rat exposed to toluene. Ind. health 13 (1975) 109 $-114$.

137. TAKEUCHI, Y., TANAKA, T., MATSUMOTO, T. and MATSUSHITA, T. Experimental studies on the response of diencephalon-hypophysis-adrenal cortex system in exposure to toluene vapor (in Jap- anese with English summary). Jpn. $j$. ind. health 14 (1972) $543-553$.

138. TALYOR, G. J. and HARRIS, W. S. Glue sniffing causes heart block in mice. Science 170 (1970) 866-868.

139. TEISINGER, J. and SRBOVA, J. L'élimination de l'acide benzoique dans l'urine et son rapport avec la concentration maximum tolérable de toluene dans l'air. Arch. mal. prof. med. trav. secur. soc. 16 (1955) 216-220.

140. TOKUNAGA, R., TAKAHATA, S., ONODA, M., ISHI-I, T., SATO, K., HAYASHI, $M$. and IKEDA, M. Evaluation of the exposure to organic solvent mixture: Comparative studies on detection tube and gas-liquid chromatographic methods, personal and stationary sampling, and urinary metabolite determination. Int. Arch. Arbeitsmed. 33 (1974) 257-268.

141. TRUHAUT, R. Transformations metaboliques des toxiques organigues. Interet de leur stude. Ann. pharm. fr. 11 (1963) $46-78$.

142. ULFVARSON, U. Fördeling av lösningsmedel mellan blod och luft. II. Upptag av gasförmig luftföroreningar hos exponerade människor som funktion av fördelingskoefficienten mellan blod och luft. Prövning av en modell (Arbete och hälsa no. 7). Arbetarskyddsverket, Stockholm 1976, pp. 9-20.

143. ULFVARSON, U. and ÖVRUM, P. Fördeling av lösningsmedel mellan blod och luft: I. Bestämning av fördelingskoefficienten mellan blod och luft för nảgra lättflyktiga lösningsmedel (Arbete och hälsa no. 7). Arbetarskyddsverket, Stockholm 1976, pp. 1-7.

144. UNGVÁRY, G., HUDAK, A., BORS, Z. and FOLLY, G. The effect of toluene on the liver assayed by quantitative morphological methods. Exp. mol. pathol. 25 (1976) $49-59$.

145. VLASTIBOROVÁ, A. and FRIBORSKÁ, A. Nucleoli of lymphocytes in peripheral blood of persons exposed to toluene. Folia haematol. (Leipzig) 99 (1973) 230-232.

146. WILLIAMS, R. T. Detoxication mechanisms: The metabolism and detoxication of drugs, toxic substances and other organic compounds (2nd ed.). Chapman \& Hall Ltd., London 1959. 781 p.

147. WILSON, R. H. Toluene poisoning. J. am. med. assoc. 123 (1943) 1106-1108.

148. WINSTON, S. and MATSUSHITA, T. Permanent loss of chromosome initiation in toluene-treated Bacillus substilis cells. J. bacteriol. 123 (1975) 921-927.

149. WIRTSCHAFTER. Z. T. and CRONYN, M. W. Free radical mechanism for solvent toxicity. Arch. environ. health 9 (1964) 186-191.

150. WOLF, M. A., ROWE, V. K., MC COLLISTER, D. D., HOLLINGSWORTH, R. L. and OYEN, F. Toxicological studies of certain alkylated benzenes and benzene. Arch. ind. health 14 (1956) 387-398. 